\title{
THE CONCEPTUAL IDEA OF HAPPINESS IN G.S. KOSTIUK'S PSYCHOLOGICAL SYSTEM
}

In Happiness And Contemporary Society : Conference Proceedings Volume (Lviv, March, 20-21, 2021). Lviv: SPOLOM, 2021. P. 99-101. https://doi.org/10.31108/7.2021.21

ISBN 978-966-919-697-2

ДРИГУС Марія

\section{КОНЦЕПТУАЛЬНА ІДЕЯ ЩАСТЯ У ПСИХОЛОГІЧНІЙ СИСТЕМІ Г.С. КОСТЮКА}

// Щастя та сучасне суспільство : збірник матеріалів міжнародної наукової конференції (Львів, 20-21 березня 2021 р.). - Львів : СПОЛОМ, 2021. С. 99-101. https://doi.org/10.31108/7.2021.21

ISBN 978-966-919-697-2 
https://doi.org/10.31108/7.2021.21

\author{
DRIHUS Maria \\ PhD in Psychology, Senior Researcher \\ G.S. Kostiuk Institute of Psychology of National Academy of Educational \\ Sciences of Ukraine (Kyiv, Ukraine)
}

\title{
THE CONCEPTUAL IDEA OF HAPPINESS \\ IN G.S. KOSTIUK'S PSYCHOLOGICAL SYSTEM
}

G.S. Kostiuk, a prominent scientist and the founder of Ukrainian psychology, initiated the consideration of «happiness - personality» approach, continuing also in the modern national psychological space. He applied this approach for the first time into the theoretical and methodological analysis of personality formation and development. Such point of view was innovative and unique for the Ukrainian psychological science at the 60s of the twentieth century and testifies to G.S. Kostiuk's unique ability to anticipate the key problems of current time. The thesis presents G.S. Kostiuk's conceptual idea of happiness in connection to his theoretical and methodological foundations for personality development. Our scientific research shows that G.S. Kostiuk used the idea of happiness for the first time in the Ukrainian psychological science for the comprehensive analysis of an individual's abilities, as well as ontogenetic analysis of a "growing personality». The idea of happiness was also included into the concept of an individual's professional self-determination, developed by the scientist, which was an innovation for his time. G.S. Kostiuk described the architectonics of an individual's professional self-determination and revealed "the source of an individual's personal happiness" connected with such self-determination, and such approach was unique.

KEY WORDS: personality, happiness, development, abilities, professional selfdetermination.

\author{
ДРИГУС Марія \\ кандидат психологічних наук, старший науковий співробітник \\ Інститут психології імені Г.С. Костюка Національної академії \\ педагогічних наук України (Київ, Україна)
}

\section{КОНЦЕПТУАЛЬНА ІДЕЯ ЩАСТЯ У ПСИХОЛОГІЧНІЙ СИСТЕМІ Г.С. КОСТЮКА}

Проблема щастя у вимірі психологічного благополуччя особистості є однією з гостро злободенних у сучасному суспільному просторі. Дослідницькі пошуки іï розв'язку віддзеркалюються у розмаїтті концептуальних парадигм, репрезентованих на міжнародних наукових форумах [5; 6]. Особлива значущість проблеми щастя з необхідністю вимагає з'ясування іiї історіогенези.

Прикметно, що у сучасному вітчизняному психологічному просторі розгляд парадигми «щастя - особистість» ініціював видатний учений, фундатор вітчизняної психології Г.С. Костюк. Саме йому належить першість її включення до теоретико-методологічного аналізу становлення та розвитку особистості. Це було інноваційним і непересічним для вітчизняної психології 60 -х років ХX ст. і 
свідчить про унікальну здатність антиципації Г.С. Костюком ключових проблем сучасності.

Абрисно розглянемо деякі спектри включення Г.С. Костюком концептуальної ідеї щастя до теоретико-методологічних засад розвитку особистості.

Здійснені нами наукові пошуки свідчать про те, що саме у праці «Здібності та їх розвиток у дітей», яка вийшла друком у 1963 році, Г.С. Костюк уперше у вітчизняному психологічному просторі включає до розгляду концептуальну ідею щастя у процесі усебічного аналізу сутності здібностей [2].

Розкриваючи «поняття про здібності», учений підкреслює: «...це - істотні психічні властивості людської особистості, що виявляються в ії цілеспрямованій діяльності і зумовлюють іiі успіх» [4, с. 307-308]. Розглядаючи ціннісний аспект розвитку здібностей, Г.С. Костюк чітко означує його у парадигмі «повноти особистого щастя кожної людини». Це було першим включенням концептуальної ідеї щастя до теоретико-методологічного аналізу проблеми розвитку особистості та іiі здібностей. Учений зазначає: «Всебічний розвиток здібностей людини потрібний для активної участі всіх людей у створенні необхідних для суспільства матеріальних і духовних цінностей... і повноти особистого щастя кожної людини» [4, c. 307].

Г.С. Костюк здійснив грунтовний теоретико-методологічний аналіз проблеми розвитку здібностей «підростаючої особистості» на різних етапах іiі онтогенезу, розкрив технологію становлення $\mathrm{i}$ розвитку особистості - психологічно благополучної, особистісно ефективної, успішної у діяльності та продуктивної у власній генезі особистісного саморозвитку. Учений створив своєрідну матрицю щастя особистості, різнобічно окреслюючи вектори - «успіх/неуспіх», продуктивне/деструктивне» - ii становлення, а також розкрив шляхи, що забезпечують ефективний розвиток/саморозвиток особистості.

Звертає на себе увагу ще один важливий спектр - включення Г.С. Костюком ідеї щастя у концептуальне поле розкриття проблеми професійного самовизначення особистості. У 1967 році учений присвячує їй спеціальну працю «Професійне самовизначення як фактор формування особистості» [3]. Посутньо Г.С. Костюк створив, за нашим означенням, фундаментальну концепцію професійного самовизначення, у якій синергійно розкрив психологічний зміст професійного самовизначення особистості, його становлення й перебіг у освітньому середовищі [1]. Самобутнім було включення Г.С. Костюком парадигми - «джерела її особистого щастя» - до архітектоніки професійного самовизначення особистості. Акцентуємо на тому, що у період домінантності суспільних чинників стрижнем теоретико-методологічних досліджень ученого $є$ особистість особистісний вектор для нього є визначальним.

Насамкінець зазначимо, що фундаментальні творчі надбання видатного вченого, фундатора сучасної вітчизняної психології Г.С. Костюка не мають часових меж і відкривають нові сенсотвірні змісти дослідження особистості у парадигмі щастя та її психологічного благополуччя.

\section{ЛIТЕРАТУРА}

1. Дригус, М.Т. (2020). Парадигма «особистісна ефективність - професійне самовизначення особистості» у психологічній концепції Г.С. Костюка. 
Актуальні проблеми психології : Збірник наукових праць Інституту психології імені Г.С. Костюка НАПН України. IX (13), 107-115.

2. Костюк, Г.С. (1963). Здібності та їх розвиток у дітей. Київ : Знання.

3. Костюк, Г.С. (1967). Професійне самовизначення як фактор формування особистості. Радянська школа. (3), 1-8.

4. Костюк, Г.С. (1989). Навчально-виховний процес i психічний розвиток особистості. Л.Н. Проколієнко (ред.). Київ : Радянська школа.

5. Щастя та цивілізаційний розвиток : збірник матеріалів міжнародної науковопрактичної конференції. 14-15 листопада, 2019. Львів, Україна.

6. Щастя та сучасне суспільство : збірник матеріалів міжнародної наукової конференції. 20-21 березня, 2020. Львів, Україна : СПОЛОМ. https://doi.org/10.31108/7.2020 